\title{
Being a 'citizen' in the smart city: Up and down the scaffold of smart citizen participation
}

Paolo Cardullo and Rob Kitchin,

NIRSA, National University of Ireland Maynooth, County Kildare, Ireland.

Paolo.Cardullo@nuim.ie, Rob.Kitchin@nuim.ie

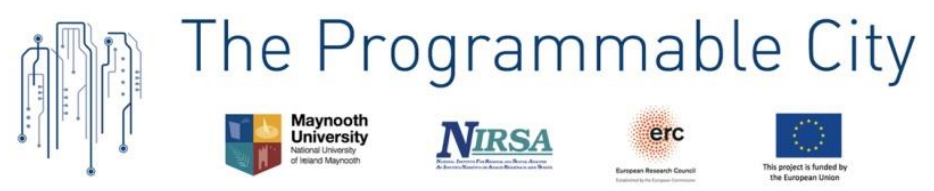

The Programmable City Working Paper 30

http://progcity.maynoothuniversity.ie/ 15 May 2017

Published as an open access pre-print on SocArXiv: https://osf.io/preprints/socarxiv/v24jn

\begin{abstract}
This paper critically appraises citizens' participation in the smart city. Reacting to critiques that the smart city is overly technocratic and instrumental, companies and cities have reframed their initiatives as 'citizen-centric'. However, what 'citizen-centric' means in practice is rarely articulated. We draw on and extend Sherry Arnstein's seminal work on participation in planning and renewal programmes to create the 'Scaffold of Smart Citizen Participation' - a conceptual tool to unpack the diverse ways in which the smart city frames citizens. We then use this scaffold to measure smart citizen inclusion, participation, and empowerment in smart city initiatives in Dublin, Ireland. Our analysis illustrates how most 'citizen-centric' smart city initiatives are rooted in stewardship, civic paternalism, and a neoliberal conception of citizenship that prioritizes consumption choice and individual autonomy within a framework of state and corporate defined constraints that prioritize market-led solutions to urban issues, rather than being grounded in civil, social and political rights and the common good. We conclude that significant normative work is required to rethink 'smart citizens' and 'smart citizenship' and to remake smart cities if they are to truly become 'citizen-centric'.
\end{abstract}

Key words: smart city, citizens, participation, engagement, citizenship, rights 


\section{Introduction}

Who decides? Who controls the resources, the design of projects, how services are run, the level of participation conferred, and for what purposes? (Wilcox 1994)

In 1969, Sherry Arnstein published a highly influential paper on the ways in which citizens are involved in the planning process and regeneration programmes. ${ }^{1}$ As a heuristic device for structuring and illustrating her argument she formulated a conceptual ladder with eight rungs 'corresponding to the extent of citizens' power in determining the end product' (1969: 217; see Table 1). At the lower end of the ladder we find forms of 'non-participation' ('manipulation' and 'therapy'), which are designed to direct and educate people in a top-down, formal manner, steering and controlling them, rather than engaging them in a form of dialogue, feedback or cocreation. She then defines 'tokenism' as a form of participation in which people have 'voice' and some degree of autonomy, though they rarely are able to change directly the status quo of decisions and plans already taken elsewhere. The corresponding rungs of the ladder here are: 'informing', in which citizens are provided information which can shape their choice- and decision-making; 'consultation', in which citizens are invited to provide feedback; and 'placation', in which citizens are able to propose suggestions for interventions. The final three rungs of Arnstein's ladder concern 'citizen power': these forms of participation include 'partnership', in which citizens can act as co-creators, taking an active participative role and sharing decision-making with dominant power-holders; 'delegated power', in which citizens are full actors and have a dominant decision-making role; and, at the top of the ladder, 'citizen control', where 'have-not citizens obtain full managerial power' (Arnstein 1969: 217).

Table 1: Arnstein's (1969) ladder of citizen participation in planning

\begin{tabular}{|l|l|}
\hline \multicolumn{2}{|c|}{ Form and Level of Participation } \\
\hline Citizen Power & Citizen Control \\
\cline { 2 - 2 } & Delegated Power \\
\cline { 2 - 2 } & Partnership \\
\hline \multirow{2}{*}{ Tokenism } & Placation \\
\cline { 2 - 2 } & Consultation \\
\cline { 2 - 2 } & Informing \\
\hline Non-participation & Therapy \\
\cline { 2 - 2 } & Manipulation \\
\hline
\end{tabular}

1 To date, the paper has almost $14 \mathrm{k}$ citations in Google Scholar. 
Arnstein was not an academic - at the time the paper was published she was working as advisor and consultant at the US Department for Housing. Her understanding of citizen participation therefore reflects an insider's perspective into federal programmes of urban renewal and anti-poverty intervention, very much formed around her practice-based and policyoriented experience, rather than from a theoretical approach rooted in citizenship, rights and political theory more broadly. In Arnstein's formulation, the quality and depth of citizen participation in planning is rooted in access to power. Although she never defines power, Arnstein maintains the control of power has significant implications to the socio-economic advancement of 'have-nots' with respect to decision-making processes and the distribution of resources. It is clear that to her, power is the means through which citizens can change sociopolitical goals according to their own 'views, aspirations, and needs' and thus embodies the potential to transform 'nobodies' into 'somebodies' (1969: 217). Participation is linked to power to the extent it can induce 'significant social reform', affecting the outcome of a process and eventually redistributing 'the benefits of affluent society', rather than being only an 'empty ritual' (p. 216). In other words, for Arnstein, participation and power can work together by reflecting an ideal of society that is more equal and just with respect to plan- and decisionmaking.

Arnstein herself noted shortcomings with her conceptual tool, detailing that the ladder is a 'simplification' which reduces the diversity of participatory situations to only eight rather than '150 rungs with less sharp and 'pure' distinctions among them' (1969: 217). Since its publication, the ladder has attracted numerous critiques, especially with regards to the variable through which her ideal of participation develops: power. Some scholars suggest that citizens' empowerment and participation might not be the desired goal for a society at any given time (Collins and Ison, 2009; Wilcox, 1994), and note that just because citizens have control of a service does not mean this will be any more inclusive. Participation with control does not guarantee equality or equity for all. ${ }^{2}$ Others seek to reclaim the role of 'the expert' in the decision-making process, whom with their domain-level expertise act on behalf of citizens especially with regards to healthcare (Tritter and McCallum, 2006) or education (Hart, 2008). Using domain-level experts - bureaucrats, technocrats, specialist workers - creates efficiencies and utilises accreted knowledge to tackle issues that citizens may have little experience or knowledge of. When there are limited resources and high expectations for success, citizencontrolled initiatives potentially carry a high overhead in time and effort, and a high degree of

\footnotetext{
2 e.g., if White supremacists are co-creators in a planning initiative, while they gain control and influence it is at the expense of other groups who are excluded.
} 
uncertainty and a risk of non-delivery (Carr 2007). Other scholars, although in agreement with political and critical approaches which foreground power and social change, ask whether ladder-type schematics are the most appropriate way to structure and discuss the complexity and the multiplicity that participation entails (Wilcox 1994; Carpentier 2016). A ladder, they argue, creates an overly linear and evolutionary analysis, with forms of participation ordered in a way that demarcate their relative value and utility - with, for example, 'citizen control' deemed more worthy and vital than 'therapy', despite the fact that therapy might provide a greater improvement in quality of life (see Carpentier, 2016). Wilcox (1994) thus reconceptualises the ladder into five stances rather than rungs: information, consultation, deciding together, acting together, and supporting independent community interests. While he still orders them by level of engagement, he does not suggest any one stance is better than another; it is rather 'a matter of 'horses for courses", with 'different levels appropriate at different times to meet expectations of different interests' (p.4).

Beyond Arnstein's work and various attempts to reformulate her conceptual ladder is a vast literature concerning citizen engagement and participation in the management and governance of society, citizenship and political rights, planning, and community development. While we are cognisant of this work and debates, which are too extensive to summarize here, we feel it is worthwhile persisting with Arnstein's ladder. While the ladder is certainly open to critique, its popularity endures due to its heuristic utility to think through the extent to which citizens are involved in formulating and participating in how services are conceived and delivered. In this paper, we leverage the utility of the ladder, reworking and expanding on Arnstein's original formulation in order to address some of its shortcomings, using our modified schematic to consider how citizens are framed in the smart city. In effect, we produce a 'Scaffold of Smart Citizen Participation' and use this to examine the degree to which the smart city is 'citizen-centric'.

This application has value, we believe, because the use of smart city technologies (e.g., city operating systems, urban control rooms, coordinated emergency management response systems, intelligent transport systems, smart grids, smart lighting, mobile/locative media, sensor-networks, etc.) are being rolled out extensively in cities around the world. The use of these technologies have been critiqued for being overly technocratic and top-down in orientation, enacting forms of algorithmic governance that controls and disciplines citizens, as well as being tools to produce and reinforce neoliberal logics of urban management: that is, they serve the interests of states and corporations more than they do those of citizens (see Greenfield 2013; Kitchin 2014; Vanolo 2014; Datta 2015; Sadowski and Pasquale 2015; Luque- 
Ayala and Marvin 2016; Kitchin et al., 2017a). In response to such criticism, the developers, promoters and deployers of smart city technologies have sought to reposition smart city initiatives as being 'citizen-' or 'community-focused'. For example, the European Union has branded its funding programmes for creating smart cities the 'European Innovation Partnership for Smart Cities and Communities' (EIPSCC) with a dedicated 'citizen-focused' strand of funded projects. Likewise, cities such as Dublin have branded their overarching smart city initiative (Smart Dublin ${ }^{3}$ ) as 'Open, Engaged, Connected', where 'engaged' relates to citizen engagement. In their marketing material, companies such as IBM and Cisco have declared that their solutions are 'citizen-focused'. ${ }^{4}$

Despite the re-orientation towards creating 'smart citizens' to date there has been little critical conceptual scrutiny as to how citizens are imagined and engaged by different smart city technologies (though see Gabrys 2014; de Lange and de Waal 2013; Vanolo 2016; Cowley et al., 2017). That is not to say that there have been few attempts to conceive and enact more 'citizen-centric' smart city initiatives, such as the large number of civic hacking and living lab projects. Rather, there has been little attempt to systematically unpack conceptually the diverse ways citizen participation is being conceived and enacted in the smart city.

\section{The scaffold of smart citizen participation}

Reflecting on both the critique of Arnstein's ladder and how citizens have been framed within smart cities discourse, it is evident that Arnstein's formulation needs to be expanded and refined in order to more fully account for the type, role, function, political discourse/framing, and modality of smart citizen participation. At the same time, there is little merit in trying to provide a comprehensive list of ' 150 rungs'. Our aim is not then to be exhaustive, but rather to provide a useful heuristic device to identify how smart city initiatives conceive of citizen participation. We have thus reworked Arnstein's ladder using its original framework but broadening it to provide a wider conceptual scaffolding (see Table 2).

Our initial reworking of the ladder was to add a ninth rung to the level of participation column: 'choice'. This is to recognize that, in the almost fifty years since Arnstein was writing, states have embraced neoliberalism, with city services and infrastructures being increasingly marketised (treating citizens as customers) and privatised (corporations own key city assets and performing many key roles) (Brenner and Theodore 2002). As such, a prime way in which a

\footnotetext{
3 https://www.smartdublin.ie

4 https://www.ibm.com/smarterplanet/us/en/smarter_cities/overview/

http://www.cisco.com/c/en/us/solutions/industries/smart-connected-communities.html
} 
Table 2: Scaffold of Smart Citizen Participation

\begin{tabular}{|c|c|c|c|c|c|c|}
\hline \multicolumn{2}{|c|}{ Form and Level of Participation } & \multirow{2}{*}{$\begin{array}{c}\text { Role } \\
\text { Leader/ } \\
\text { Member }\end{array}$} & \multirow{3}{*}{ 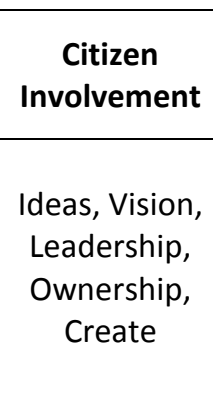 } & \multirow{3}{*}{ 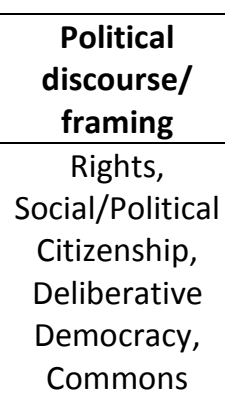 } & \multirow{4}{*}{$\begin{array}{c}\text { Modality } \\
\\
\text { Inclusive, } \\
\text { Bottom-up, } \\
\text { Collective, } \\
\text { Autonomy, } \\
\text { Experimental }\end{array}$} & \multirow{2}{*}{$\begin{array}{c}\begin{array}{c}\text { Dublin } \\
\text { Examples }\end{array} \\
\begin{array}{c}\text { Code for Ireland, } \\
\text { Tog }\end{array}\end{array}$} \\
\hline \multirow{3}{*}{ Citizen Power } & $\begin{array}{l}\text { Citizen } \\
\text { Control }\end{array}$ & & & & & \\
\hline & $\begin{array}{l}\text { Delegated } \\
\text { Power }\end{array}$ & $\begin{array}{c}\text { Decision- } \\
\text { maker, Maker }\end{array}$ & & & & $\begin{array}{l}\text { Civic Hacking, } \\
\text { Hackathons, } \\
\text { Living Labs, }\end{array}$ \\
\hline & Partnership & Co-creator & $\begin{array}{c}\text { Negotiate, } \\
\text { Produce }\end{array}$ & \multirow[b]{2}{*}{$\begin{array}{l}\text { Participation, } \\
\text { Co-creation }\end{array}$} & & Dublin Beta \\
\hline \multirow{3}{*}{ Tokenism } & Placation & Proposer & Suggest & & \multirow{8}{*}{$\begin{array}{l}\text { Top-down, } \\
\text { Civic } \\
\text { Paternalism, } \\
\text { Stewardship, } \\
\text { Bound-to- } \\
\text { succeed }\end{array}$} & $\begin{array}{c}\text { Fix-Your-Street, } \\
\text { Smart Dublin } \\
\text { Advisory } \\
\text { Network }\end{array}$ \\
\hline & Consultation & $\begin{array}{l}\text { Participant, } \\
\text { Tester }\end{array}$ & Feedback & \multirow[b]{2}{*}{$\begin{array}{c}\text { Civic } \\
\text { Engagement }\end{array}$} & & $\begin{array}{l}\text { CIVIQ, Smart } \\
\text { Stadium }\end{array}$ \\
\hline & Information & Recipient & \multirow{4}{*}{$\begin{array}{c}\text { Browse, } \\
\text { Consume, } \\
\text { Act }\end{array}$} & & & $\begin{array}{c}\text { Dublinked, } \\
\text { Dublin } \\
\text { Dashboard, RTPI }\end{array}$ \\
\hline \multirow{3}{*}{ Consumerism } & \multirow{3}{*}{ Choice } & Resident & & \multirow{3}{*}{$\begin{array}{l}\text { Capitalism, } \\
\text { Market, } \\
\text { Neoliberalism }\end{array}$} & & $\begin{array}{l}\text { Smart building/ } \\
\text { Smart district }\end{array}$ \\
\hline & & Consumer & & & & Smart meters \\
\hline & & Product & & & & $\begin{array}{c}\text { Personal data } \\
\text { generated by } \\
\text { tech }\end{array}$ \\
\hline \multirow{2}{*}{$\begin{array}{c}\text { Non- } \\
\text { Participation }\end{array}$} & Therapy & \multirow{2}{*}{$\begin{array}{l}\text { Patient, } \\
\text { Learner, } \\
\text { User, } \\
\text { Data-point }\end{array}$} & \multirow{2}{*}{$\begin{array}{l}\text { Steered, } \\
\text { Nudged, } \\
\text { Controlled }\end{array}$} & \multirow{2}{*}{$\begin{array}{l}\text { Stewardship, } \\
\text { Technocracy, } \\
\text { Paternalism }\end{array}$} & & $\begin{array}{l}\text { Smart Dublin, } \\
\text { Dublin Bikes }\end{array}$ \\
\hline & Manipulation & & & & & Traffic control \\
\hline
\end{tabular}

citizen interacts with the smart city is as a 'consumer', selecting which services to acquire from the marketplace of providers. As consumers, the services that people purchase - or, in the case of free-to-use apps, swap personal data for - are designed and created by companies with limited involvement by citizens. The second role citizen performs at this level is that of 'resident' with those who can afford the purchase/rent price able to choose to live in a 'smart building' or 'smart district', spaces that are often exclusive, gated communities. An additional role that citizens perform is that of 'data product', creating data through their use of smart city technologies that companies can then extract value from by mining them for the purposes of micro-marketing or trading with data brokers. Consumption in the smart city is 'citizen-centric' in as far as it seeks to provide a selection of information and services from a range of entities that fulfil a need. We have therefore slotted it into our scaffold between 'Non-Participation' and 'Tokenism' in a new category 'Consumerism'. 
Our main alterations have been to add a number of related columns, some categories of which span Arnstein's rungs - hence, our use of scaffold rather than ladder. The first column added relates to the role expected of/adopted by citizens with respect to smart city initiatives. We have identified sixteen roles that shift from passive and lacking control to active and responsible from bottom-to-the-top of the scaffold. The second column added concerns the form of citizen involvement enacted by citizens and the nature of their engagement, varying from forms of coercion through to visioning and steering initiatives. The third additional column refers to the political discourse used to justify and drive the various forms, levels, roles and involvement of citizens. The final additional column is the modality in broad terms as to how citizens are positioned vis-à-vis the smart city. In the lower half of the scaffold initiatives are most often top-down in conception, being devised by city administrations or corporations, and are broadly underpinned by notions of stewardship (for citizens) and civic paternalistic (deciding what is best for citizens) (Clark and Shelton 2016). These projects are 'bound-tosucceed' in the sense that there is an expectation that these initiatives will deliver on their promise to produce a 'smarter' city and not waste taxpayers' money or shareholder investment. In contrast, in the top half of the table, initiatives are more bottom-up in conception, being devised in part or in whole by citizens, and are more collective in how they operate. These initiatives are often more experimental in nature and it is understood that they might fail to create a long-term, sustainable outcome. For example, smart city hackathons are often as much about the process of civic hacking as they are about producing a working solution (Perng et al., 2017). We discuss these additions below in detail, using examples drawn from empirical research in Dublin, Ireland.

\section{The forms and levels of citizen participation in Dublin}

\section{Non-participation}

'Non-participation' occurs when citizens are nudged and steered towards specific sets of behaviour, practice, and conduct. In Arnstein's words, initiatives that promote 'manipulation' and 'therapy' have the objective of 'enabl[ing] power holders to 'educate' or 'cure' the participants' (1969: 217). This can be the case for interventions that require very little input from citizens other than to use or experience an algorithmically-mediated service for the purposes of governmentality. In the case of smart city technologies the algorithmic governance enacted utilises the production of big data that intensifies the extent and frequency of monitoring and shifts the governmental logic from surveillance and discipline to capture and 
control' (Kitchin et al., 2017a: 3). Here, citizens become subject to a modulation of their actions through software-mediated systems. A variety of practices of control are exerted by the technocratic smart city systems - intervention, self-disciplining, mediation, coordination, direction, optimization, and co-option - each designed to produce particular regulatory outcomes that actively shape behaviour (Kitchin et al., 2017a). For example, navigating a traffic network controlled by an intelligent transport system, or walking down a street lit by smart lighting.

In the case of Dublin, traffic flow is regulated by the Traffic Management and Incident Centre (TMIC) and its use of SCATS (Sydney Coordinated Adaptive Traffic System) (McCann 2014). SCATS is an automated and adaptive system whose primary role is to manage the dynamic timing of signal cycles and phases at road junctions in order to ensure the optimal flow. The system automatically calibrates the cycles and phases dependent on a set of programmed rules and the flow, speed, and density of traffic for each lane of traffic in previous cycles and phases (as measured in real-time by a network of 800 inductive loop sensors) (McCann 2014; Coletta and Kitchin 2016). In addition, the TMIC has access to 380 CCTV cameras, a small number of Traffic Cams (traffic sensing cameras), a mobile network of approximately 1,000 bus transponders, phone calls and messages by the public to radio stations and operators, and social media posts (Coletta and Kitchin 2016). Citizens and their vehicles become data-points in a fluctuating system, with the data generated used to calibrate the system and traffic flow. Information from the system is also pushed out to citizens via apps, the Dublin Dashboard, ${ }^{5}$ real-time passenger information at bus-stops, and on-street signs stating numbers of vacant spaces in car parks, which nudge decision-making with respect to choice of route and parking.

Citizens caught in processes of data-gathering or automatic activation of utilities are 'users' with very limited rights and possibilities for changing outcomes. For Gabrys (2014), in projects involving citizen-sensing such as environmental monitoring, the citizen is a 'datapoint' that provides information with often little access to, and no political capital to act upon, those data. She further suggests that strategies of monitoring and efficiency using environmental sensors and programming of environments generate ambividuals: 'ambient and malleable urban operators that are expressions of computer environments' (Gabrys, 2014: 42). The outcome is here double: on the one hand, the participant provides data necessary to the success of the project, being co-opted in neoliberal discourses of efficiency and environmental

\footnotetext{
5 http://www.dublindashboard.ie
} 
sustainability; on the other, the citizen is steered and controlled by way of nudging, that is, gently persuaded of how to conduct a way of life contained within optimal or ideal targets usually around environmentally friendly use of resources or care of own body. Here, a citizen is also a 'patient' who is to be 'cured', encouraged to act in certain ways defined by others. As Davies (2015: 11) rightly suggests, 'any critique of ubiquitous surveillance must now include a critique of the maximization of well-being'. This is because 'happiness monitoring tools flood our lives' and many smart technologies serve exactly the scope of 'measurement and commercialization of our feelings and emotions'. The coming together of behavioural surveillance and science of happiness have produced, according to Davies, a 'cottage industry of decision experts, ready to predict how an individual will behave under different circumstances' (2015: 239). Such information can be used to nudge individuals to act in certain ways, thus 'non-participation' melds into 'choice', while 'user' turns into 'consumer' (see Isin and Wood 1999).

Personal views can also be reshaped through education and social learning. With respect to smart cities there is a highly active and organised epistemic community (networks of knowledge and policy experts that share a common set of normative beliefs and practices) and advocacy coalition (stakeholders and vested interests who promote the use of ICT solutions in urban management) who seek to influence the decision-making of city administrations, who in turn need to school citizens and local politicians as to the benefits of smart urbanism (Kitchin et al., 2017b). Organizing occurs across a number of scales from the global (e.g., Smart Cities Council), to the supranational (e.g., EIPSCC), to the national and the local. In the case of Dublin, 'Smart Dublin' is a shared initiative of the four city authorities that seeks to coordinate and promote smart city initiatives. It tries to influence city worker attitudes to the notion of smart cities through social learning in the form of workshops, sponsoring pre-procurement challenges, and fostering collaborative projects between local authority departments and companies. With respect to citizens, it communicates its work through its website and creates social learning through organizing/sponsoring hackathons. In this way, workers and citizens are educated to the logic of smart cities.

Non-participation in the smart city is underpinned by a strong technocratic impulse (aspects of the city can be treated as technical problems that can be addressed by technical solutions), and notions of stewardship and civic paternalism. Here, initiatives are citizen-centric to the extent that they might be conceived and delivered on behalf of, or in the best interests of, citizens. However, citizens are little if ever consulted in how initiatives are formulated or deployed. Their participation is thus narrowly framed in a very instrumental way. Moreover, 
accountability by service providers is sometimes lacking because smart city initiatives are often delivered by what Swyngedouw (2005: 1992) terms 'beyond-the-state' or 'hybrid configurations'; that is, the recent proliferation of flexible and decentered models of urban governance - 'forms of apparently horizontally organised and polycentric ensembles, associational networks of private (market), civil society (usually NGO) and state actors ... dealing with social, economic, infrastructural, environmental or other matters'. The proliferation of new administrative units, quangos, public-private agencies and 'experts' (middle management, external contractors, data analysts, chief innovation officers), and the splintering of infrastructural provision, further dissipate a transparent and democratic process. Indeed, many smart city initiatives and cooperative projects with companies are implemented by agencies with little, if any, political oversight. This has certainly been the case in Dublin where the chief executives of local authorities can action initiatives without necessarily obtaining the sanction of councillors.

\section{Consumerism}

There are now thousands of app-driven services designed to transform city living. The vast majority of these are owned and operated by private corporations who utilise digital technologies to deliver new services. These services are often 'disruptive innovations' (Christensen 1997) that radically alter established orders. For example, the sharing economy is transforming the taxi (e.g., Uber) and accommodation (e.g., Airbnb) industries, as well as employment practices (e.g., the gig economy) (McLaren and Agyeman 2015). The companies providing such services argue that they are leveraging new technologies for the benefit of citizens by providing efficient, responsive services at lower cost than traditional providers. Moreover, competition between companies ensures consumer choice and continued competitiveness. Similarly, urban services traditionally delivered by city administrations are being privatised or delivered through service contracts with private corporations or publicprivate partnerships. Here, citizens are recast from citizens with rights and entitlements, who receive a service in return for taxation, to consumers who select from a marketplace of options. For example, in a deregulated energy marketplace, consumers can choose an electricity supplier who competes for business by offering different tariffs and services. In the case of a residence fitted with a smart meter they can also monitor their consumption using an app and can choose when to use electricity to minimize cost (e.g., timing a washing machine to operate when unit costs are low). 
In addition, people can embrace a 'smart lifestyle' by becoming a resident in a smart building or district. Such buildings and areas are often served by multiple smart city technologies designed to enhance the lives of residents through improved security, energy and waste services, and transportation and parking options. These buildings/areas are often quite exclusive and form gated communities, available only to those that can afford the purchase/rent price. Indeed, it seems that the adoption of smart technologies in such spaces are seen as a key means of marking them as an exclusive development and attracting a certain kind of investment/investor. Certainly, places such as Songdo in South Korea - a privately-owned, model smart city built on reclaimed land - are gated communities at neighbourhood/city-scale (Kitchin 2016a). The exclusivity and 'smartness' of the development is a core part in its ambition to become an urban growth machine that helps attract additional international realestate investment and foreign-direct investment through the creation or relocation of high-tech jobs (Kim 2010; Shin et al., 2015). Similarly, developments such as Hudson Yards in New York - presently the largest, single real-estate project in the United States - is marketing itself as a smart city initiative for the same reasons (Mattern 2016). In Dublin, the 'Silicon Docks' area of the city - a special development zone being regenerated through a mix of high-end offices and residential apartments - has recently been designated a 'smart district' (Heaphy and Pétercsák 2016). Home to the European headquarters of companies such as Google, Facebook and Linkedin, the area is to become a testbed for new smart technologies and act as means to attract additional inward investment (especially from urban Internet of Things companies). Much of the space created is privately owned and managed rather than being public space, with such developments operating for the benefit of their owners and counter to that of an urban commons. A 'smart citizen' in such developments is a high-income consumer seeking an exclusive property investment with the latest technological trimmings, rather than necessarily being concerned with producing more sustainable, diverse, participatory communities.

In such a framing, citizens/residents are very much cast as consumers within a marketplace of smart products and lifestyles. However, they are consumers who have a narrow range of control. That is, they are afforded a choice of services/products, but the choice is often quite constrained in two ways. First, the systems on offer are largely pre-determined in nature, with the consumer reduced to tinkering with parameters rather than being able to radically reconfigure the service. Second, the choice between services is often limited to a couple of providers who have quickly gained monopoly positions, or are built to work on platforms that are monopolies. In general, services are designed and operated with limited involvement by citizens other than as users. If citizens are involved, it is usually as feedback during 
requirement's analysis in the design phase or as beta-testers of products in the production phase. Here, feedback is used to tweak already conceived designs, rather than to form the bedrock for design thinking. Like 'non-participation', 'consumerism' is then undergirded by a strong technocratic framing. It also has strong notions of stewardship and paternalism, with the market largely determining what is in the best interests of citizens.

Importantly, citizens play another role to consumer/resident when using marketprovided smart city initiatives - that of 'product'. Smart city technologies generate vast quantities of big data - that is, data that are produced in real-time and are exhaustive and finegrained in nature (Kitchin 2014). For example, using a locative media app generates highly granular data about a person's movements and the places they visit; using a public wifi point generates data about browsing habits; walking past a series of bins or lampposts fitted with a MAC address tracker records a person with a smartphone's route. Indeed, all smart city technologies, whether engaged with passively (such as being monitored by an automatic number plate recognition camera) or actively (e.g., using a service), produce data that can be mined for insights, traded with and between data brokers, and conjoined with other data for the purposes of social sorting, predictive profiling, micro-marketing, and anticipatory governance (Kitchin 2014). City administrations are seen as a key target market for harvested data, with a number of companies seeking to sell citizen data to cities for the purposes of improving planning and service delivery. For example, Waze has sought to sell congestion data and Uber origin-destination data to cities for the purpose of transport planning. The casting of citizens as data products raises a series of ethical questions concerning over-extended and intrusive surveillance as well as privacy and predictive privacy harms that have barely begun to be examined and redressed legally (Kitchin 2016b).

\section{Tokenism}

'Tokenism' within Arnstein's terms essentially concerns various degrees of public engagement and citizen 'voice'. In its lower form, engagement consists of 'informing'. Here, a citizen is a 'recipient' of useful information. For example, citizens can access open data that, on the one hand, inform them as to what is happening in the city, and on the other, can be repurposed to form the input for citizen-created apps (assuming they have the skills and time to do so). In Dublin, Dublinked $^{6}$ - an initiative co-owned by the four local authorities - is the city's open data store, sharing a mix of administrative and operational data, including some real-time

\footnotetext{
${ }^{6}$ http://www.dublinked.ie
} 
datasets related to transport and environment. Much of these data, along with statistical data and administrative data published by other government agencies, are made available to the public through the Dublin Dashboard as interactive maps, graphs and apps (Kitchin et al., 2016). Such information can be used to shape decision-making and also be used to create transparency and accountability with regards to the actions and decisions of administrations (a key argument of the open data movement). However, while 'informing' can be highly useful, it is often uni-directional, with limited or no channel for feedback provided. Moreover, information is often provided after key planning and decision-making processes have occurred, leaving little or no room for change.

In its higher forms, tokenism constitutes 'consultation' and 'placation' in which citizens gain a 'voice'. In 'consultation' citizens are provided with information about proposed courses of action and are requested to provide feedback representing their views. Various forms of social media and online tools have multiplied the possibilities for citizen consultation (Seltzer and Mahmoudi 2013; de Waal, 2014). In the Dublin case, an example would be the use of CIVIQ, an online consultation tool that enables citizens to comment on and discuss draft county development plans. ${ }^{7}$ Another form of consultation is through user-testing and feedback, which can often occur without citizens being aware that it is occurring. For example, in the Smart Stadium $^{8}$ initiative internet of things prototypes are being trialled for monitoring crowd behaviour, service performance, and stadium management. Here, feedback is given passively through mere presence and action.

In 'placation' rather than simply feedback on proposals, citizens are able to suggest alternatives and additions to those proposed. In Dublin, an example is Fix-Your-Street, ${ }^{9}$ wherein citizens can use an online tool to report the location of issues that need to be addressed (such as potholes, graffiti, broken streetlights, illegal dumping), thus suggesting an alternative work programme for city workers. Smart Dublin also has appointed an advisory network of forty key stakeholders drawn from government, companies, universities and civil society that meets twice a year to offer constructive feedback on Dublin's smart city initiatives.

'Consultation' and 'placation' do enable citizens to engage with and potentially reshape the plans and actions of city administrations. They are promoted as being citizen-focused since they facilitate feedback and the suggestion of alternative solutions to centrally formulated plans.

\footnotetext{
7 http://www.civiq.eu/

8 At Croke Park Stadium, an 80,000 seater venue owned and operated by the Gaelic Athletics Association. https://dcu.asu.edu/content/smart-stadium

9 http://fixyourstreet.ie/
} 
They can thus work to keep civic paternalism in check by challenging the aspirations and assertions of 'experts' and politicians. Nonetheless, Arnstein labels the processes of 'informing', 'consultation' and 'placation' as 'tokenistic' arguing that they are framed by and largely reproduce the dominant interests of city administrations. Citizens are asked to contribute to a set of initiatives which are already largely predetermined in their scope and how they will operate. In this sense, they are enabled to partially re-arrange the deckchairs on a ship's deck, but not to determine how the ship is run or its general course. In turn, city administrators are able to claim they involved citizens in their planning and decisions, but questions remain as to whom has the real decision-making power and how a proposed change is implemented. As Arnstein (1969: 217) notes, in 'tokenism', 'there is no follow through, no 'muscle', hence no assurance of changing the status quo'.

In addition, 'consultation' and 'placation' suffer from the same issues that plague crowdsourcing initiatives in general: a bias towards the views of well-educated, technologically-literate participants (Crutcher and Zook 2009); a difficulty in sustaining a productive crowd long-term; superficial and sometimes ignorant feedback on complex issues (Carr 2007); and how to document degrees of validity, reliability and trustworthiness of the data generated (Dodge and Kitchin 2013). In this sense, although smart technologies seek to promote engagement, they might deepen structural barriers to socio-political participation related to education, class, gender, age and ethnicity. Moreover, the crowdsourcing process involves the donation of free labour by citizens in the production of new markets for consultation services, wherein consultation online platforms gain authored content (feedback), plus subsidiary authored information such as comments, tags, ratings, and cross-linking URLs that constitute valuable meta-content, which can be packaged and traded to third parties (Dodge and Kitchin 2013). A potential by-product of citizen engagement then is citizens and their views sliding down the scaffold to 'product'. For Arnstein, the solution to these tokenistic forms of participation was what she termed 'citizen power'.

\section{Citizen Power}

At the top of Arnstein's ladder were what she argued were more rewarding and representative forms of civic participation in which citizens have 'increasing degrees of decision-making clout' (1969, p. 217). She details that 'partnership' involves a redistribution of power from those traditionally in control to citizens, enabling communities to negotiate and engage in tradeoffs with established, powerful stakeholders, such as city administrations. In effect, planning and decision-making is shared, with agreed ground rules and mechanisms for moving projects 
forward and resolving impasses. 'Delegated power' occurs when citizens gain the dominant decision-making authority and genuine specified powers within a co-shared initiative. Such is the strength of the citizen's position that a bargaining process is required to resolve differences rather than traditional power holders simply forcing a position. 'Citizen control' occurs when citizens are fully in charge of the policy and managerial aspects of a program or institution and 'can negotiate the conditions under which 'outsiders' may change them' (1969, p. 223).

Within the smart city, there are as yet relatively few cases of widely deployed 'citizen power'. In Dublin, for example, it is difficult to identify an example of 'partnership' or 'delegated power' where initiatives are co-owned and co-created, and citizens share or have the dominant decision-making authority. Usually, examples are drawn from community development initiatives that are undertaken through a partnership between a community organisation and the state, but such initiatives have not yet been created with regards to the smart city. Where co-creation does occur it is usually through short-term hackathons or civic hacking/living lab projects. With respect to hackathons, citizens are invited to participate in a weekend long event design to produce prototype technical solutions to city issues. There have been a number of such hackathons sponsored by the Dublin local authorities, along with corporate partners such as IBM and Intel, with respect to using the city's open data and producing smart city applications. While citizens who attend are free to produce whatever application they desire, the event is very much owned and run by the sponsors, who frame the event aims and provide space, mentors and guidance. In most cases, a primary aim of such events is to stimulate innovation and to create viable prototypes for marketable products. In the Dublin case, a number of prototypes have been further developed post-event into commercial enterprises, such as Building Eye ${ }^{10}$ and Parkya. ${ }^{11}$ From this perspective, hackathons are a means to kindle and maintain business-led urban development and entrepreneurial urban governance (Perng et al. 2017), rather than producing citizen- or community-led smart city solutions. Such an orientation is reflected in the participants in civic hacking events, which are dominated by young men working in the IT sector who often view the event as a means to advance their careers (Perng et al. 2017).

In Dublin and elsewhere, there have recently been a number of Living Labs initiatives that adopt Lo-Fi technologies, such as Arduino motherboards packed with environmental sensors for the monitoring of noise or air pollution. ${ }^{12}$ These initiatives typically work with a

\footnotetext{
${ }^{10}$ https://www.buildingeye.com/

${ }^{11}$ https://parkya.com/

12 https://fablabbcn.org/0000/01/06/smart-citizen.html
} 
community of interest (e.g., residents affected by noise pollution in Amsterdam $)^{13}$ and are usually university- or industry-led. An example of a local authority-led initiative was Dublin Beta, which closed in early 2017. For a handful of years it trialled street-based pop-up initiatives working with local citizens, though most were low- or no-digital tech in nature (such as pop-up parks and secure bike sheds in parking bays, new gutter run-off systems, painting street infrastructure to discourage vandalism) (Perng 2016). While such initiatives do involve citizens, the form and level of participation is often circumscribed. As Gabrys (2014: 38) suggests, in citizen-sensing 'participation involves computational responsiveness', rather than initiating a political debate or enabling citizens to make rights claims. In other words, participation is often instrumental rather than empowering in a political sense. In addition, in projects led by one or a handful individuals initiatives are often hamstrung by decision-making processes being dominated by a 'benevolent dictator' (Ljungberg, 2000). In the Dublin Beta case, the project was led by a single Dublin City Council employee who drove the entire initiative. There are also concerns as to the extent to which Living Labs using formerly vacant space, or being deployed in regeneration programmes, act as gateways for gentrification (Cardullo and Kitchin 2017).

It seems that in cases where participation and co-creation are initiated by those in power, rather than from the bottom-up by citizens themselves, the ideals of shared or citizen-dominated decision-making sought by Arnstein are rarely present. Cope (2017) recently noted that creating a smart city project that actively involves citizens in its governance and operation is difficult in practice because the mechanisms through which such initiatives are formulated can create predetermined hierarchical pathways. This is the case for any initiative that requires large-scale financial investment from a grant agency, philanthropy body, or bank, as this can usually only be applied for by a government agency or company. In general, what happens is the government agency/company makes a pitch for funding for a project that is designed to deliver certain outcomes (e.g., reduce energy or increase sustainable transport) and only when it has the funding in hand does it seek to engage with local communities. In part, this is because putting together a large, multimillion euro bid is time-consuming and a complex task, and because there are no supports either financial or staffing to facilitate a citizen-led bid. Any engagement that occurs after funding, even if designed to be citizen-focused, has then to meet pre-determined milestones and fulfil the deliverables of the contract, meaning citizens have limited scope to reframe the initiative around their concerns and desires.

\footnotetext{
${ }^{13}$ http://www.sensornet.nl/english
} 
There are, however, a handful of examples of 'citizen control' in Dublin. These include Code for Ireland ${ }^{14}$ (an initiative owned and run by citizens to produce civic apps) and $\operatorname{Tog}^{15}$ (a community maker initiative). In each case, the initiative is wholly owned and organised by citizens for citizens. Citizens decide on the projects to be pursued and undertake the required development and implementation work. Unlike hackathons, the work usually unfolds over months, with team members meeting weekly or monthly to advance a project. As with all such initiatives, the projects are full of frictions and negotiation, with teams rarely staying stable and the outcome a compromise and gerry-rigged solution (Perng and Kitchin 2016).

While Arnstein views 'citizen power' as the pinnacle for creating cities that reflect the desires and aspirations of citizens, our discussion has illustrated how in practice bottom-up, inclusive, empowering citizen involvement in key decision-making about cities is difficult to achieve. In the case of the smart city there are to date few successful examples of co-produced and citizen-led initiatives. Sharing or crowdsourcing apps have largely been co-opted within an economic frame, and are owned by companies rather than communally (McLaren and Agyeman 2015). Those initiatives that do exist are typically small, involving very few individuals (in the Dublin case a couple of hundred citizens in a population of 1.2 million). In part this is because there has been little sustained grassroots attempts to create community-led smart cities, with communities tending to organize their activities and activism around addressing social and environmental issues through political and policy solutions rather than technological ones. In part, it is because the imperative for creating smart cities is being driven by a neoliberal ideology and corporate interests that dominate the landscape and circumscribe a particular role for citizens which is highly instrumental.

Even within those initiatives that are closest to enacting 'citizen power', how citizens are expected, and expect themselves, to participate is largely practical and instrumental in nature, rather than grounded in a much more political discourse of rights, citizenship and urban commons. It is as if the smart city has been so successfully framed as neoliberal and postpolitical (Swyngedouw 2016) that being a 'smart citizen' is simply understood as living in and seeking to implement a smart city. Indeed, even when citizens perform roles such as participants, co-creators, decision-makers, or owners, they are largely still cast within a neoliberal logic of choice, consumption and individual autonomy framed by state and corporate defined and legitimized constraints which prioritize market-led solutions to urban issues (Isin and Wood 1999). In other words, they are performed within the bounds of expected and

\footnotetext{
${ }^{14}$ http://codeforireland.com/

15 https://www.tog.ie/
} 
acceptable behaviour, rather than transgressing or resisting social and political norms, and express a form of neoliberal citizenship grounded in anticipated roles and personal responsibilities and obligations, rather than civil, social and political rights and the public or common good.

\section{Conclusion: Being a smart citizen in the smart city}

Our aim in this paper has been to unpack how citizens are framed within smart city initiatives. To this end, we have reworked Arnstein's (1969) ladder of citizen participation to create a 'scaffold of smart citizen participation' that, we believe, provides a useful heuristic device for evaluating the extent to which a smart city initiative is citizen-centric. We have utilised this scaffold to assess the smart city initiatives of Dublin, Ireland. Our scaffold makes it clear that there are numerous roles that citizens play in the smart city. Indeed, citizens can perform all of the roles and functions identified in Table 2 and can experience, at the same time, different forms of participation (non-participation, consumerism, tokenism, citizen power). And, as our Dublin examples illustrate, cities can simultaneously host all kinds of smart initiatives designed to interact with and serve citizens in different ways and produce a diverse range of citizen participation. These initiatives are seemingly framed within, and promote and enact, a set of overlapping and competing politics. However, with the exception of some 'citizen power' initiatives (which can be rooted in notions of social and political citizenship, rights, commoning, and deliberative democracy), all levels of the scaffold are consistent with neoliberal citizenship and its emphasis on personal autonomy, consumer choice, individuals performing certain roles and taking responsibility for their own life chances, the marketization and privatisation of services and infrastructures, and the state facilitating and stewarding neoliberal forms of governmentality and governance and market-led solutions to urban issues (Vanolo 2015; Kitchin et al., 2017b).

As such, while citizen participation is potentially diverse, it is most often framed in a post-political way that provides feedback, negotiation, participation and creation, but within an instrumental rather than normative or political frame. In other words, citizens are encouraged to help provide solutions to practical issues - such as producing an app, or feeding back on a development plan, or to perform certain roles/responsibilities - but not to challenge or replace the fundamental political rationalities shaping an issue or plan. Moreover, the opportunities to participate in the upper rungs of the scaffold are limited. From 'placation' upwards, the number of active citizens experiencing 'citizen power' is tiny in relation to the overall population. Even the numbers taking part in 'consultation' and 'information' (using open data, city dashboards) 
are relatively low (a few thousand). Indeed, as Isin and Wood (1999) note, people have differential resources and competencies to claim and assert citizenship. Instead, most citizens are 'empowered' in the smart city by technologies that treat them as consumers or testers, or people to be steered, controlled, and nudged to act in certain ways, or as sources of data which can be turned into products. This hardly makes them 'smart' citizens.

It seems to us then that there is significant normative work to be done to rethink 'smart citizens' and 'smart citizenship' drawing on the rich literature that has sought to argue for the 'right to the city' (Lefebrve 1996; Mitchell 2003), and new notions of digital (Isin and Ruppert 2015) and urban citizenship (Staeheli 2013). Such normative thinking and the development of an alternative vision of smart citizenship is beyond the aims and scope of this paper. It is interesting to note that beyond the academy some of this reconceptualization is already underway. For example, Barcelona is presently attempting to formulate and implement a different vision of a smart city and smart citizenship. Under a right-wing, neoliberal government, in the early 2010s Barcelona became the poster child for the smart city through its various smart city initiatives and aggressive self-promotion and the hosting of the Smart City Expo and World Congress. Since May 2015, however, with the election of a left-wing, green, social movement coalition, the city has transformed its vision of a smart city to one that is much more citizen-centric and grounded in notions of social and political citizenship (March and Ribera-Fumaz 2017). In the first year after taking office, the new city administration froze the issuing of new contracts for smart city initiatives and undertook an evaluation of existing ones. In mid-2016 a new Commissioner of Technology and Digital Innovation was appointed and a new selection of smart programs initiated. In October 2016 the city published 'Barcelona Ciutat Digital: A Roadmap Towards Technological Sovereignty'. ${ }^{16}$ Here, Barcelona as a smart city is re-envisioned as an 'open, fair, circular and democratic city', with its mission '[to] solve city and citizens challenges through a more democratic use of technology' (March and RiberaFumaz 2017). Barcelona has thus sought to re-politicize the smart city and to shift its creation and control away from private interests and the state toward grassroots, civic movements and social innovation (March and Ribera-Fumaz 2017).

It remains to be seen whether the re-orientation under way in Barcelona will work in practice, or whether the neoliberal model of smart citizenship prevalent previously and elsewhere will be reasserted. Regardless, in our view, if smart cities are going to be populated by 'smart citizens' then city administrations should be seeking to shift as many of its initiatives

\footnotetext{
${ }^{16}$ http://ajuntament.barcelona.cat/estrategiadigital/uploads/BCN_Digital.pdf
} 
as possible up the scaffold towards citizen engagement and citizen power. Ideally, this would also involve a reframing of paternalistic and market-driven notions of smart citizens towards one rooted in a form of citizenship underpinned by rights and entitlements. This is not to be blind to the fact that cities need to deliver efficient, reliable and cost-effective services, or that companies do provide a range of innovative solutions to urban problems, or that there is a necessary role for experts and expert knowledge. Rather, it is to suggest that these need to be mobilised within a different frame of reference that is avowedly citizen-centric, not state- or capital-centric. The normative challenge then to creating truly 'citizen-centric' smart cities will be to re-imagine the role citizens are to play in their conception, development and governance.

\section{Acknowledgements}

The research for this paper was provided by a European Research Council Advanced Investigator Award, 'The Programmable City' (ERC-2012-AdG-323636). Many thanks to Sung-Yueh Perng, Claudio Coletta, Cesare di Feliciantonio, and the attendees of the 'Is Another Smart City Possible?' sessions at the Association of American Geographers meeting in Boston, April 2017, for useful reflections and comments.

\section{References}

Arnstein SR (1969) A ladder of citizen participation. Journal of the American Institute of Planners 35(4): 216-224.

Brenner N and Theodore N (2002) Cities and the geographies of 'actually existing neoliberalism'. Antipode 34(3): 349-379.

Cardullo P and Kitchin R (2017) Living Labs, vacancy, and gentrification. The Programmable City Working Paper 22, socarxiv. Available from: https://osf.io/preprints/socarxiv/waq2e (accessed 17 March 2017).

Carpentier N (2016) Beyond the ladder of participation: an analytical toolkit for the critical analysis of participatory media processes. Javnost - The Public 23(1): 70-88.

Carr NG (2007) The Ignorance of Crowds. strategy+business. Available from: http://bit.ly/2pvWkLZ (accessed 24 April 2017).

Christensen CM (1997) The Innovator's Dilemma. Boston: Harvard Business School Press. Available from: http://www.hbs.edu/faculty/Pages/item.aspx?num=46 (accessed 24 April 2017). 
Clark J and Shelton T (2016) Technocratic values and uneven development in the 'smart city'. Metropolitics. Available from: http://www.metropolitiques.eu/Technocratic-Values-andUneven.html (accessed 16 February 2017).

Coletta C and Kitchin R (2016) Algorhythmic governance: Regulating the 'heartbeat' of a city using the Internet of Things. The Programmable City Working Paper 22, socarxiv. Available from: https://osf.io/bp7c4/ (accessed 28 December 2016).

Coletta C, Heaphy L and Kitchin R (2017) From accidental to articulated smart city: The creation and work of Smart Dublin. The Programmable City Working Paper 28, socarxiv. Available from: https://osf.io/preprints/socarxiv/93ga5 (accessed 15 May 2017).

Collins K and Ison R (2009) Jumping off Arnstein's ladder: social learning as a new policy paradigm for climate change adaptation. Environmental Policy and Governance 19(6): $358-373$.

Cope G (2017) Learning for citizen participation in smart city planning. Paper presented at the Association of American Geographers, Boston. April 5-9.

Cowley R, Joss S and Dayot Y (2017) The smart city and its publics: insights from across six UK cities. Urban Research \& Practice: 1-25.

Crutcher M and Zook M (2009) Placemarks and waterlines: Racialized cyberscapes in postKatrina Google Earth. Geoforum 40(4): 523-534.

Datta A (2015) New urban utopias of postcolonial India: 'Entrepreneurial urbanization' in Dholera smart city, Gujarat. Dialogues in Human Geography 5(1): 3-22.

Davies W (2015) The Happiness Industry: How the Government and Big Business Sold Us Well-Being. London: Verso.

de Lange M and de Waal M (2013) Owning the city: New media and citizen engagement in urban design. First Monday 18(11). Available from: http://firstmonday.org/ojs/index.php/fm/article/view/4954 (accessed 1 February 2017).

de Waal M (2014) The City as Interface: How Digital Media Are Changing the City. Reflect, Rotterdam: nai010 publishers.

Dodge M and Kitchin R (2013) Crowdsourced cartography: mapping experience and knowledge. Environment and Planning A 45(1): 19-36.

Gabrys J (2014) Programming environments: environmentality and citizen sensing in the smart city. Environment and Planning D: Society and Space 32(1): 30-48.

Greenfield A (2013) Against the Smart City. 1.3 edition. New York: Do projects.

Hart RA (2008) Stepping back from 'the ladder': reflections on a model of participatory work with children. In: Reid A, Jensen BB, Nikel J, et al. (eds), Participation and Learning, 
Dordrecht: Springer Netherlands, pp. 19-31. Available from:

http://link.springer.com/10.1007/978-1-4020-6416-6_2 (accessed 25 March 2017).

Heaphy L and Pétercsák R (2016) Building smart city partnerships in the 'Silicon Docks'. Paper presented at the Creating Smart Cities workshop, Maynooth University, Ireland. Available from: http://bit.ly/2mjmyfd.

Isin EF and Ruppert E (2015) Being Digital Citizens. London: Rowman \& Littlefield. Isin EF and Wood PK (1999) Citizenship and Identity. London: Sage.

Kim C (2010) Place promotion and symbolic characterization of New Songdo City, South Korea. Cities 27(1): 13-19.

Kitchin R (2014) The Data Revolution: Big Data, Open Data, Data Infrastructures \& Their Consequences. London: Sage.

Kitchin R (2016a) Impressions of Songdo, an urban growth machine in progress. The Programmable City. Available from: http://tiny.cc/scbkgy (accessed 2 November 2016).

Kitchin R (2016b) The ethics of smart cities and urban science. Philosophical Transaction A 374(2083): 1-15.

Kitchin R, Maalsen S and McArdle G (2016) The praxis and politics of building urban dashboards. Geoforum 77: 93-101.

Kitchin R, Coletta C, Leighton E, et al. (2017a) Smart cities, urban technocrats, epistemic communities and advocacy coalitions. The Programmable City Working Paper 26, socarxiv. Available from: https://osf.io/aqak7 (accessed 24 April 2017).

Kitchin R, Coletta C and McArdle G (2017b) Urban informatics, governmentality and the logics of urban control. The Programmable City Working Paper 25, socarxiv. Available from: https://osf.io/276px/.

Lefebvre H (1996) The right to the city. In: Kofman E and Lebas E (eds), Writings on cities, Cambridge, Mass: Blackwell.

Ljungberg J (2000) Open source movements as a model for organising. European Journal of Information Systems 9(4): 208-216.

Luque-Ayala A and Marvin S (2016) The maintenance of urban circulation: An operational logic of infrastructural control. Environment and Planning D: Society and Space 34(2): 191-208.

March H and Ribera-Fumaz R (2017) Against, for and beyond the smart city: Towards technological sovereignty in Barcelona. Paper presented at the Association of American Geographers, Boston. April 5-9 
Mattern S (2016) Instrumental City: The View from Hudson Yards, circa 2019. Places Journal. Available from: https://placesjournal.org/article/instrumental-city-new-yorkhudson-yards/ (accessed 27 January 2017).

McCann B (2014) A Review of SCATS Operation and Deployment in Dublin. Paper presented at the 19th JCT Traffic Signal Symposium \& Exhibition. Available from: http://bit.ly/2otveAc (accessed 24 April 2017).

McLaren D and Agyeman J (2015) Sharing Cities: A Case for Truly Smart and Sustainable Cities. MIT Press.

Mitchell D (2003) The Right to the City: Social Justice and the Fight for Public Space. New York: The Guilford Press.

Perng S-Y (2016) Creating infrastructure with citizens: Traffic Light Box Artworks in Dublin streets, paper presented at the Creating Smart Cities workshop, Maynooth University, Ireland. Available from: http://bit.ly/2mjmyfd (accessed 13 March 2017).

Perng S-Y and Kitchin R (2016) Solutions and frictions in civic hacking: collaboratively designing and building wait time predictions for an immigration office. Social \& Cultural Geography: 1-20.

Perng S-Y, Kitchin R and Mac Donncha D (2017) Hackathons, entrepreneurship and the passionate making of smart cities. The Programmable City Working Paper 28, socarxiv. Available from: https://osf.io/nu3ec.

Sadowski J and Pasquale FA (2015) The spectrum of control: A social theory of the smart city. First Monday 20(7). Available from: https://papers.ssrn.com/sol3/papers.cfm?abstract_id=2653860 (accessed 24 April 2017).

Seltzer E and Mahmoudi D (2013) Citizen participation, open innovation, and crowdsourcing: challenges and opportunities for planning. CPL bibliography 28(1): 3-18.

Shin H, Park SH and Sonn JW (2015) The emergence of a multiscalar growth regime and scalar tension: the politics of urban development in Songdo New City, South Korea. Environment and Planning C: Government and Policy 33(6): 1618-1638.

Staeheli LA (2003) Cities and citizenship. Urban Geography 24(2): 97-102.

Swyngedouw E (2005) Governance innovation and the citizen: the janus face of governancebeyond-the-state. Urban Studies 42(11): 1991-2006.

Swyngedouw E (2016) The mirage of the sustainable 'smart' city. Planetary urbanization and the spectre of combined and uneven apocalypse. In: Nel-lo $\mathrm{O}$ and Mele R (eds), Cities in the 21st Century, London: Routledge, pp. 134-143. 
Tritter JQ and McCallum A (2006) The snakes and ladders of user involvement: Moving beyond Arnstein. Health Policy 76(2): 156-168.

Vanolo A (2014) Smartmentality: The smart city as disciplinary strategy. Urban Studies 51(5): 883-898.

Vanolo A (2016) Is there anybody out there? The place and role of citizens in tomorrow's smart cities. Futures 82: 26-36.

Wilcox D (1994) The Guide to Effective Participation. Partnership Online. Available from: http://partnerships.org.uk/guide/AZpartic.html. 